\title{
Borehole water-level variations and implications for the subglacial hydraulics of South Gascade Glacier, Washington State, U.S.A.
}

\author{
ANDREW G. FOUNTAIN \\ U.S. Geological Survey, Denver, Colorado 80225, U.S.A.
}

\begin{abstract}
Boreholes were drilled in South Cascade Glacier to investigate the hydraulics of subglacial water flow. Results indicate that subglacial water pressures are generally close to local ice-overburden pressures and that a subglacial debris layer probably exists. Calculations indicate that the range of hydraulic conductivity of this layer is $10^{-7}-10^{-4} \mathrm{~m} \mathrm{~s}^{-1}$. The borehole water levels generally increased during the ablation season and may be caused by a seasonal evolution in the permeability of the debris layer. Water in the debris layer drains to a subglacial conduit, the existence of which is inferred by large diurnal variations in the water level of one borehole. These levels commonly reached the bottom of the glacier, indicating near-atmospheric pressures in the conduit.
\end{abstract}

\section{INTRODUCTION}

The level of water in a borehole drilled to the base of a glacier is used to infer the pressure of the subglacial hydraulic system. The magnitude and variation of the pressure is one fundamental measure used to define the processes of subglacial water movement. Measurements of borehole water levels and their relation to changes in glacier-surface velocity and uplift of the ice surface were used by Iken and Bindschadler (1986) to infer that part of the subglacial hydraulic system on Findelengletscher, Switzerland, was composed of linked cavities that opened and closed as the pressure changed. Changes in borehole water levels during mini-surges of Variegated Glacier showed that waves of water pressure propagated through the subglacial system; the behavior could be explained in terms of enlarging subglacial cavities (Kamb and Engelhardt, 1987).

At South Cascade Glacier, results from previous drilling efforts by Hodge $(1976,1979)$ indicated that the subglacial water pressure was close to the overburden pressure of the ice and that the pressure gradient approximated the surface slope of the glacier. The temporal pressure variations generally followed the trend of water input to the glacier over a period of several days. However, no process was proposed to explain either the pressure magnitude or variations.

Other important measures of water movement at South Cascade Glacier have indicated drainage patterns and flow hydraulics. Tracer injections were used (Fountain, 1993) to infer that the accumulation zone and part of the ablation zone is the source region for the largest of the three streams that flow from the glacier. Furthermore, the pattern of drainage indicated a funneling of water from the accumulation zone into a narrow strip through the lower ablation zone (Fig. 1). The narrow strip is thought to be a conduit, based on analysis of the electrical conductivity of stream water and stream discharge (Fountain, 1992) and conclusions drawn from the dispersion of tracers (Fountain, 1993). Existence of a conduit could be verified by borehole water-level measurements.

This paper describes water-level measurements recorded in 24 boreholes drilled to the bed of South Cascade Glacier. The water-level observations form a data set unusual for its spatial extent and its dense time series. These data are then analyzed to infer the hydraulic processes of the subglacial water movement. The data indicate that the spatial variability in water level is not simple and cannot be described by a single hydraulic process. The temporal variability of water levels indicates both short-term response to meltwater input and longterm evolution of the subglacial hydraulic system. These measurements at South Cascade Glacier indicate that the subglacial hydraulic system in a relatively simple alpine glacier is quite complex.

\section{FIELD PROGRAM}

Boreholes were drilled using a hot-water drill modified from a design by Taylor (1984). The depth of a hole was anticipated from estimates of ice thickness taken from a map of the surface and bed elevations (Hodge, 1979). When the drill stopped near the anticipated depth, water continued to run through the drill as the nozzle was raised and lowered to make sure the drill tip was not lodged against debris embedded in the ice. Only in a few instances did the drill penetrate further than a few centimeters beyond the point where it originally stopped. 


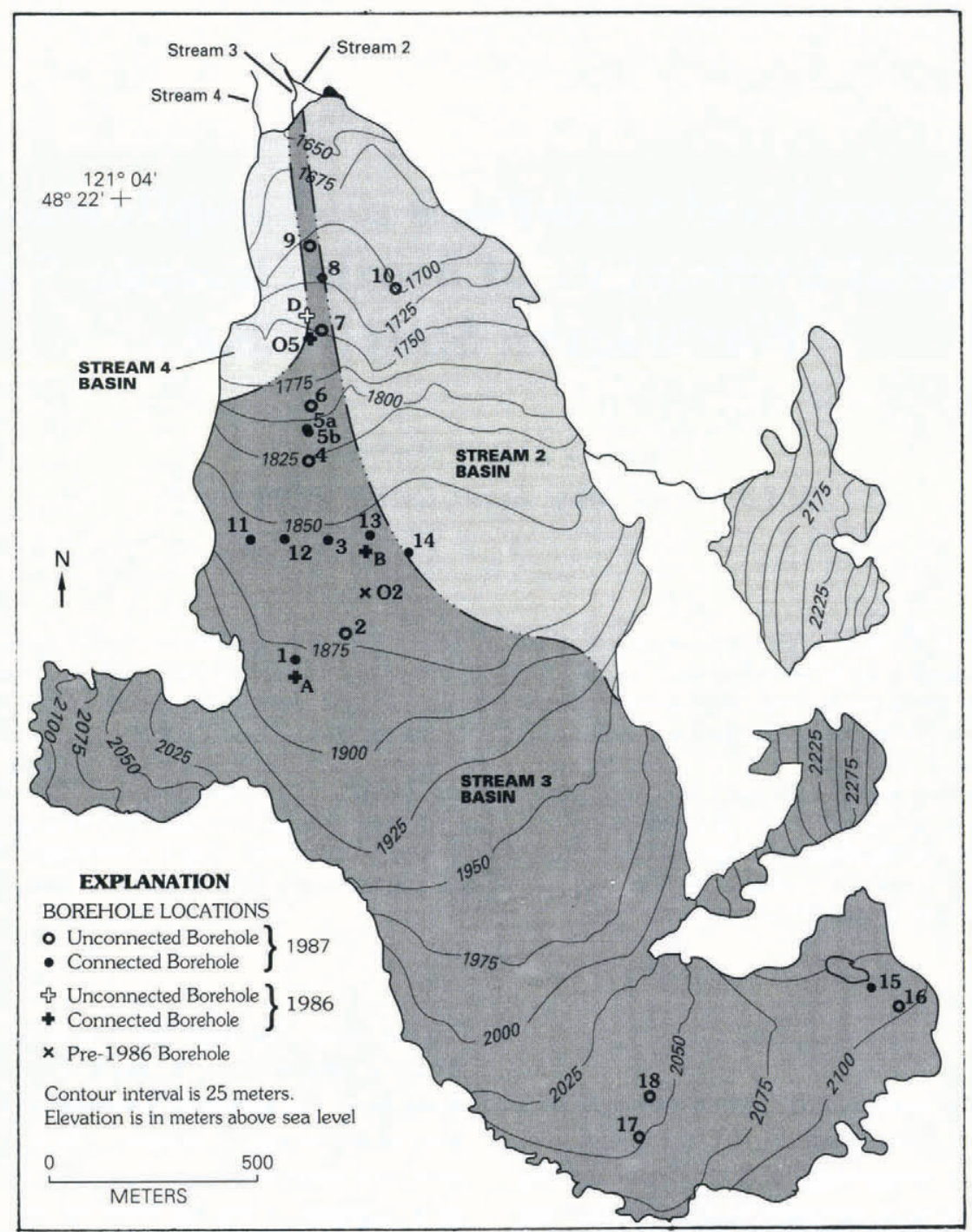

Fig. 1. Location of boreholes drilled in 1986 (plus) and 1987 (circle). The open pluses and circles indicate boreholes that did not connect to a hydraulic system and maintained water levels near the surface of the glacier during the season in which they were drilled. The closed circles and pluses indicated boreholes that did not connect. The shaded area indicates the drainage basin to stream 3 based on results of stream measurements and tracer injection (Fountain, 1992).

Once it was concluded that the drill reached the bed, the water supply was turned off and the drill was pulled to the surface. The depth of the borehole was determined from a metered pulley, which centered the hose, from the reel, over the hole. The error in measurements was usually no more than $\pm 2.5 \mathrm{~m}$.

Once a hole was completed, the water level was closely monitored for several days. In those boreholes in which the variations were a few centimeters or less, measurements were continued by hand at intermittent intervals. For those holes that exhibited water-level variations greater than a few centimeters, transducers were installed with analogue recorders. The water levels were recorded hourly and the accuracy of the measurements, including the error in the pressure transducer and transcription from the recorder, was $\pm 0.5 \mathrm{~m}$.

Over the two field seasons, 24 boreholes were drilled in 1986, denoted by letter in Figure 1 and Table 1; in 1987, 20 boreholes were drilled and are denoted by number. All boreholes, except number 10, were drilled in the glacial sub-basin that drained meltwater to the main stream, identified as stream 3 in Figure 1. This basin has an unusual drainage pattern wherein the water from the upper regions of the glacier drains through a narrow drainage strip in the lower ablation zone (Fig. 1). A longitudinal profile of 12 holes was drilled with most of the holes drilled in the ablation zone (the $1875 \mathrm{~m}$ contour in Figure 1 corresponds to the approximate position of the equilibrium line). A transverse profile of four holes was drilled above an icefall, located near the $1850 \mathrm{~m}$ contour (Fig. 1) where the drainage zone starts to narrow.

During the 1987 field season, five previously drilled boreholes were found, of which two had been drilled in 1986 and three had been drilled by S. Hodge sometime before 1982. Water levels were manually recorded in all of these old boreholes. Measurements of water-level variations in these relic boreholes showed that the variations in two boreholes ( $\mathrm{O} 2$ and $\mathrm{C}$ ) were sufficiently large to warrant automatic recording by pressure transducer. Borehole $\mathrm{O} 2$ was drilled by $\mathrm{S}$. Hodge and borehole $\mathrm{C}$ was drilled during the 1986 field season. At the end of the 1986 field season, water levels in holes C and D were at the glacier surface, whereas in 1987, the level was below the glacier surface in both holes. Unfortunately, hole D 
Table 1. Borehole data from the 1986 and 1987 field seasons

\begin{tabular}{|c|c|c|c|c|c|c|c|c|c|}
\hline \multirow[t]{3}{*}{ Borehole } & \multirow[t]{3}{*}{ Date } & \multirow{3}{*}{$\begin{array}{c}\text { Obs } \\
\text { period } \\
\mathrm{d}\end{array}$} & \multirow{3}{*}{$\begin{array}{c}\text { Bed } \\
\text { elev } \\
\mathrm{m}\end{array}$} & \multirow{3}{*}{$\begin{array}{c}\text { Ice } \\
\text { thik } \\
\mathrm{m}\end{array}$} & \multirow{3}{*}{$\begin{array}{c}\text { Mean } \\
\text { water level } \\
\mathrm{m}\end{array}$} & \multirow{3}{*}{$\begin{array}{c}\text { Mean } \\
P_{\mathrm{e}} \\
\mathrm{m}\end{array}$} & \multicolumn{2}{|c|}{ Range } & \multirow[t]{3}{*}{ Remarks } \\
\hline & & & & & & & Min & $\operatorname{Max}$ & \\
\hline & & & & & & & $\mathrm{m}$ & $\mathrm{m}$ & \\
\hline A & 29 Jul 1986 & 32 & 1710 & 175.2 & 64.6 & 92.0 & 54.0 & 86.0 & WD at $100 \mathrm{~m}$ \\
\hline B & 1 Aug 1986 & 51 & 1670 & 203.3 & $\sim 100.0$ & $\sim 81.0$ & - & - & WD at $160 \mathrm{~m}$ \\
\hline C & 14 Aug 1986 & 46 & 1673 & 83.7 & 83.7 & -9.2 & \multicolumn{2}{|c|}{ Steady } & \\
\hline $\mathrm{D}$ & 15 Aug 1986 & 46 & 1673 & 80.5 & 80.5 & 8.9 & \multicolumn{2}{|c|}{ Steady } & \\
\hline 1 & 12 Jul 1987 & 80 & 1734 & 145.5 & 86.4 & 43.1 & 60.9 & 121.5 & WD at $50.7 \mathrm{~m}$ \\
\hline 2 & 13 Jul 1987 & 79 & 1677 & 194.0 & 192.5 & 19.8 & \multicolumn{2}{|c|}{ Steady } & \\
\hline $\mathrm{O} 2$ & pre 1982 & 49 & 1675 & 161.0 & 124.1 & 19.7 & 120.4 & 125.9 & \\
\hline 3 & 15 July 1987 & 77 & 1669 & 187.2 & 152.1 & 14.5 & 131.9 & 183.6 & WD at $74.5 \mathrm{~m}$ \\
\hline 4 & 17 Jul 1987 & 75 & 1712 & 114.4 & 86.0 & 15.8 & \multicolumn{2}{|c|}{ Steady } & $W D$ at $9.6 \mathrm{~m}$ \\
\hline $5 a$ & 17 Jul 1987 & 12 & 1717 & 97.8 & 58.7 & 29.1 & - & - & \\
\hline $5 \mathrm{~b}$ & 17 Jul 1987 & 77 & 1717 & 97.8 & 58.3 & 28.7 & 56.9 & 59.9 & WD at $43.0 \mathrm{~m}$ \\
\hline 6 & $18 \mathrm{Jul} 1987$ & 76 & 1688 & 101.2 & 94.2 & -4.1 & \multicolumn{2}{|c|}{ Steady } & WD at $40.0 \mathrm{~m}$ \\
\hline 7 & 20 Jul 1987 & 74 & 1650 & 99.7 & 88.5 & 0.2 & \multicolumn{2}{|c|}{ Steady } & \\
\hline O5 & 14 Aug 1986 & 50 & 1673 & 80.5 & 55.8 & 15.8 & 50.4 & 63.1 & \\
\hline 8 & $23 \mathrm{Jul} 1987$ & 71 & 1638 & 85.2 & 65.5 & 10.3 & 61.6 & 77.8 & WD at bed \\
\hline $9 \mathrm{a}$ & 28 Jul 1987 & 66 & 1654 & 56.4 & 56.4 & -6.2 & \multicolumn{2}{|c|}{ Steady } & \\
\hline $9 \mathrm{~b}$ & 29 Jul 1987 & 65 & 1655 & 55.4 & 55.4 & -6.1 & \multirow{2}{*}{\multicolumn{2}{|c|}{$\begin{array}{l}\text { Steady } \\
\text { Steady }\end{array}$}} & \\
\hline 10 & 30 Jul 1987 & 62 & 1649 & 53.8 & 53.8 & -5.9 & & & \\
\hline 11 & 12 Aug 1987 & 50 & 1747 & 108.8 & 69.6 & 27.2 & 45.2 & 88.2 & WD at bed \\
\hline 12 & 13 Aug 1987 & 49 & 1707 & 144.4 & 32.0 & 96.5 & $<5.5$ & 127.0 & WD at $62.7 \mathrm{~m}$ \\
\hline 13 & 23 Aug 1987 & 38 & 1710 & 184.4 & 164.3 & -0.2 & 132.1 & 173.1 & WD to bed \\
\hline 14 & 24 Aug 1987 & 37 & 1710 & 148.5 & 113.2 & 19.0 & 111.5 & 126.7 & WD at $43.0 \mathrm{~m}$ \\
\hline 15 & 26 Aug 1987 & 35 & 2066 & 20.3 & 0.5 & 17.6 & 0.2 & 1.7 & WD at bed \\
\hline 16 & 26 Aug 1987 & 35 & 2035 & 52.8 & 51.6 & -4.6 & \multicolumn{2}{|c|}{ Steady } & \\
\hline 17 & 29 Aug 1987 & 32 & 1969 & 80.0 & 71.0 & 0.2 & \multirow{2}{*}{\multicolumn{2}{|c|}{$\begin{array}{l}\text { Steady } \\
\text { Steady }\end{array}$}} & \\
\hline 18 & 19 Sep 1987 & 11 & 1869 & 176.2 & 137.0 & 19.8 & & & \\
\hline
\end{tabular}

"Obs period" is the number of days that the borehole was monitored.

"Bed elev" is the bed elevation.

"Ice thik" is the ice thickness at the borehole.

"Water level" is height above bed elevation.

" $P_{\mathbf{e}}$ " is the effective pressure (ice pressure at the bed minus the water pressure) in units of meters of water.

"Steady" indicates no variation in water level more than a few centimeters was measured.

Under "Remarks", "WD" is water-level drop during drilling of the borehole and "at $x \mathrm{~m}$ " is the depth below the glacier surface of the drill tip when the drop occurred.

Boreholes $\mathrm{C}$ and $\mathrm{O} 5$ are the same hole, the different designations indicating different years of measurements.

had a constriction near the surface which prevented water-level measurements in 1987. The double label for hole $\mathrm{C}(\mathrm{O} 5)$ is used to indicate in Table 1 those measurements made in 1986 (C) and those made in 1987 (O5).

\section{WATER-LEVEL VARIATIONS DURING DRILLING}

\section{Englacial connections}

When drilling with hot water in impermeable ice, the borehole water level is maintained at the glacier's surface. Occasionally, the water level drops before the borehole reaches the bed, indicating an englacial connection (Engelhardt, 1978; Hooke and others, 1988). Of the 24 holes drilled, the water level dropped in nine holes before the bottom of the hole was reached. The depth to which the water dropped was not usually measured. Although the depth of the drill tip was recorded when the water level was observed to drop, the englacial connection may not necessarily be at that level because warm water in the hole may melt a connection to a crevasse or englacial passage anywhere along the length of the hole.

One example of a quite different process was seen in borehole 9 when the drill was $4 \mathrm{~m}$ from the bed. The water in the borehole erupted out of the borehole to a height of $2 \mathrm{~m}$, emptying much of the hole of water. About $1 \mathrm{~h}$ later, the borehole refilled with water and the water 
level remained at the surface for 2 months. Evidently, the borehole intersected a sealed cavity containing gas at high pressure.

\section{Subglacial connections}

Once the drill reaches the bed, the water-level in the borehole may start to drop. This occurred in boreholes 8 , 11,13 and 15. A typical example is borehole 11, in which the water level dropped about $28 \mathrm{~m}$ over a $7 \mathrm{~h}$ period (Fig. 2). This borehole may have connected directly with the subglacial system, by intersecting a conduit, cavity or

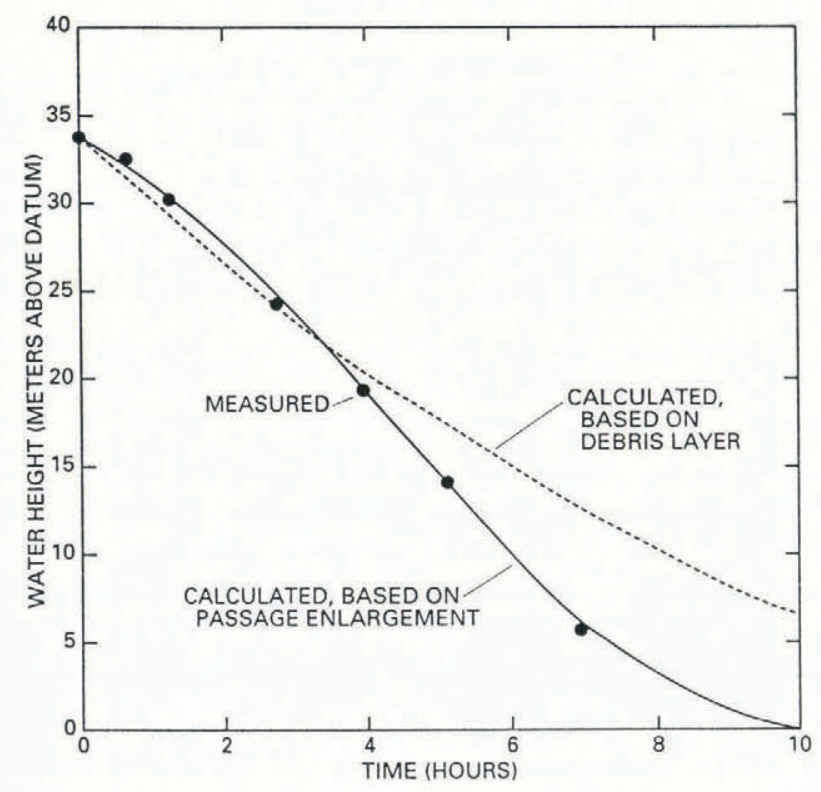

Fig. 2. Decrease in water level in borehole 11. The solid circles are measured data and the solid line is the calculated water level assuming drainage through an enlarging passage. The dashed line is the closest fit calculated water level based on drainage through a subglacial debris layer. debris layer, bed separation or indirectly via a small passage between the borehole and the hydraulic system. It is unlikely that the borehole intersected either a conduit or cavity because no variation in water level was measured in the few days that immediately followed completion of the hole. Also, calculations indicate that the borehole did not directly connect with a debris layer based on the rate at which water drains from the borehole. Another hypothesis, increasing separation between the ice and bed caused by local over-pressurization, does not explain the decreasing water level because such a process would also occur in boreholes isolated from the hydraulic system, which was not observed (Table 1).

The decrease in water level is probably controlled by an indirect connection - a subglacial passage - between the borehole and a hydraulically isolated region at lower pressure. The region is hydraulically isolated because no water-level variations were observed after connection. The englacial passage enlarges as a result from either the viscous dissipation of heat, which melts the passage walls, and/or the erosion of sediments, if the passage resides on subglacial debris. Engelhardt (1978) examined the case for the melt-enlargement of the ice-walled passage. Using Englehardt's approach, the calculations indicated that if passage was $4 \mathrm{~m}$ long, with a Manning's roughness of $0.1 \mathrm{~m}^{-1 / 3} \mathrm{~s}$ and an initial radius of $1.5 \mathrm{~mm}$, the estimated water drop matched the observed one (Fig. 2).

After the initial water-level drop in borehole 11, the water level did not significantly change until roughly 2 weeks after the borehole was completed, when the water level dropped $20 \mathrm{~m}$ and started to exhibit daily variations. This sequence was common to most connected boreholes and is in general a typical experience on other glaciers (Engelhardt, 1978; Hantz and Lliboutry, 1983; Kamb and Engelhardt, 1987). Usually, the initial water level is close to the overburden pressure of the ice, and later the water level drops and the borehole connects to the subglacial hydraulic system.

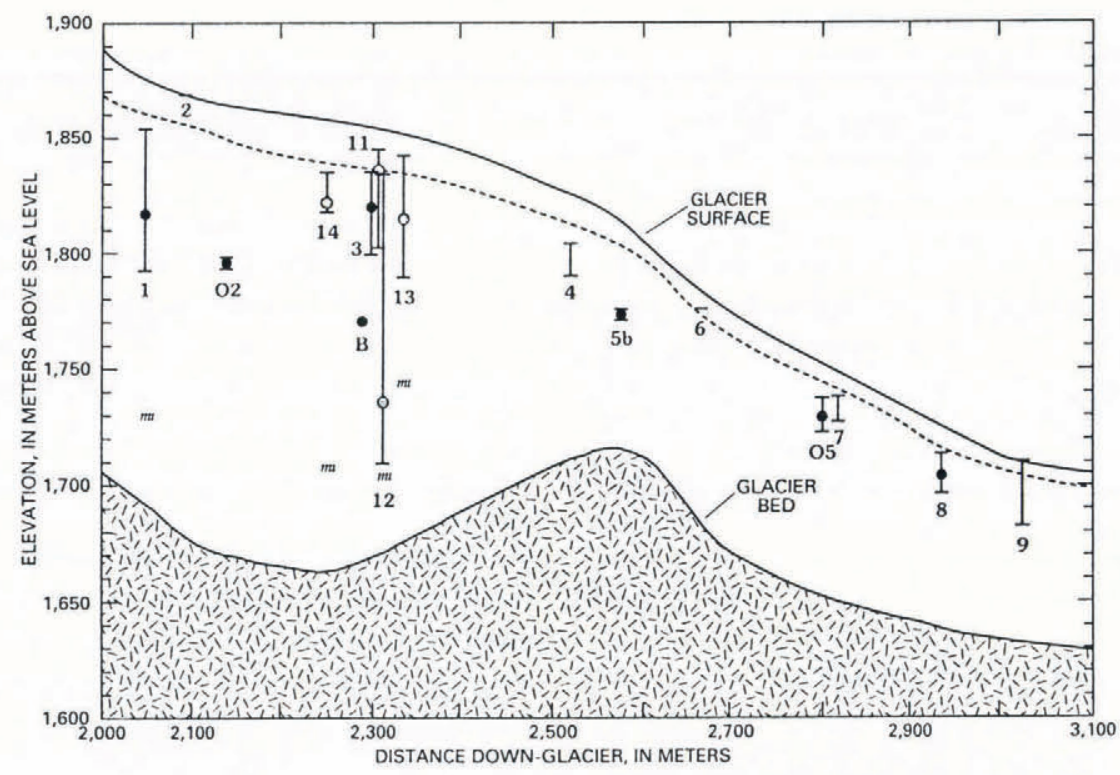

Fig. 3. Mean water levels measured in boreholes at South Cascade Glacier in 1987. The circles indicate those boreholes that were monitored on an hourly interval; the black circles are boreholes in the longitudinal profile. The shaded circles are boreholes in the transverse profile for comparison. The bars indicate the range of water levels. The dashed line is the piezometric surface of basal water if the pressure equalled the overburden pressure of the ice. The small hatched areas indicate the bed elevation under that borehole if different from the mid-line bed elevation of the glacier. 


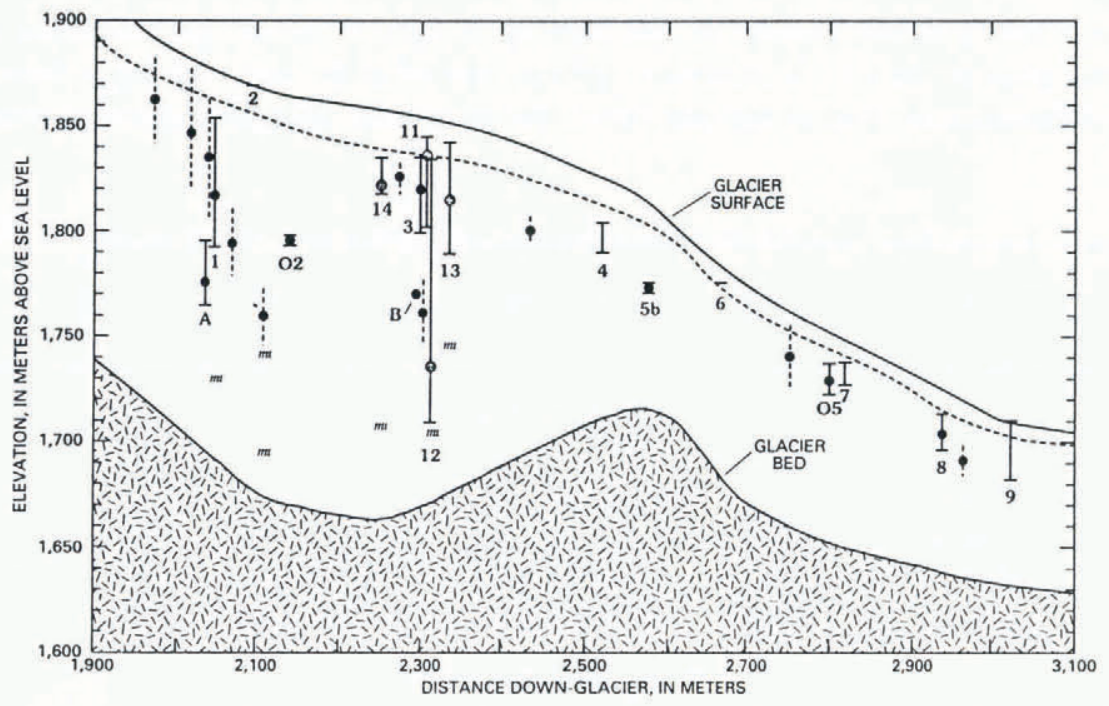

Fig. 4. The borehole water-level data including data from Hodge (1976, 1979).

\section{OBSERVATION OF BOREHOLE WATER LEVELS}

For each borehole, the water levels during the period of measurement were averaged and are summarized in Table 1. Half of the boreholes maintained water levels at or near the ice surface with little or no variation in level. These boreholes are considered isolated from the subglacial hydraulic system. The mean water levels in the boreholes are shown in Figure 3. The measured levels are typical of summer water levels at South Cascade Glacier as indicated by comparison with borehole data obtained previously by Hodge $(1976,1979)$ and plotted in Figure 4. Generally, the water levels are near the iceoverburden pressure (Fig. 3; Table 1). This observation is corroborated by earlier results of Hodge $(1976,1979)$

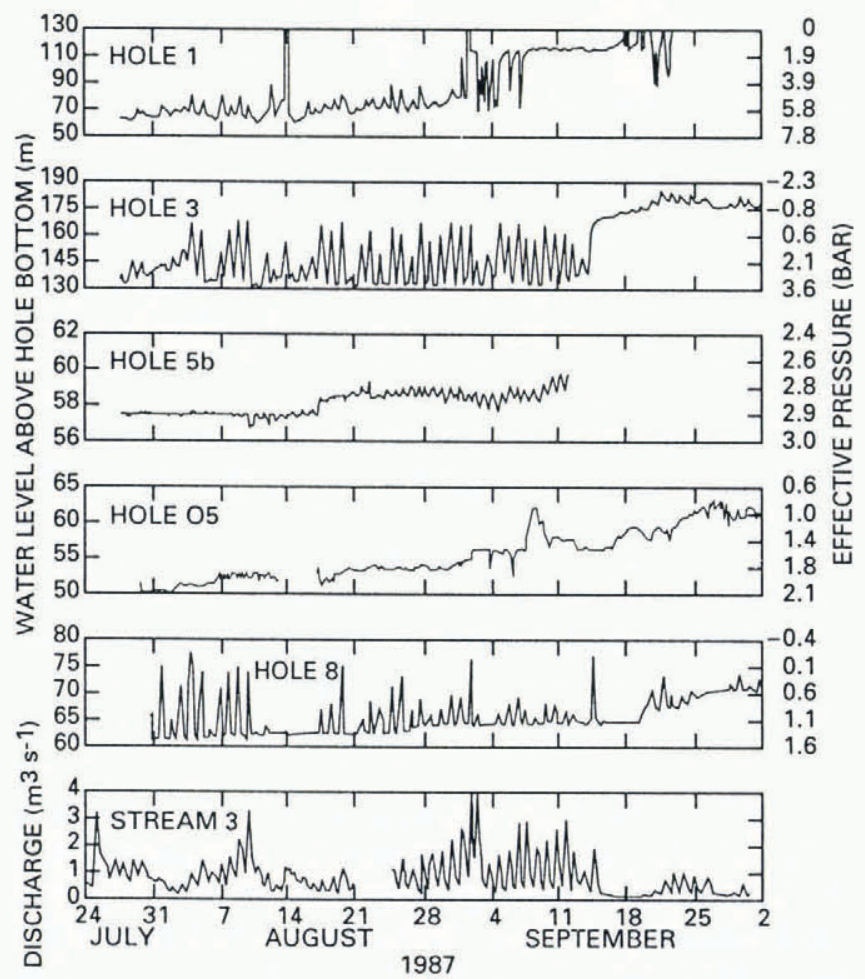

Fig. 5. Water-level variations in the boreholes in the longitudinal profile, including stream-flow.
(Fig. 4) and indicates that a high-pressure hydraulic system covers much of the subglacial region. In a few borehole, water levels are quite low, indicating regions of low subglacial water pressure. In eight of the 15 boreholes, water-level variations were recorded after the borehole was completed; results for the boreholes in the longitudinal profile $(1,3,5 \mathrm{~b}, \mathrm{O} 5,8)$ are shown in Figure 5, and results for the transverse profile $(3,11,12$, 14) are shown in Figure 6. Borehole 3 is a member of both profiles. Diurnal fluctuations are common to all boreholes except holes $\mathrm{O} 5$ and 11. Most boreholes show increasing water levels with time, except for boreholes 12 and 14 . The rate of increase may be gradual like that exhibited in boreholes $5 \mathrm{~b}, \mathrm{O} 5$ and 8 , or may be a sudden large step increase like that in boreholes 1 and 3. The timing of the diurnal variations in the boreholes and stream discharge was compared by calculating the cross-correlation between all records for different time shifts ranging from -24 to $+24 \mathrm{~h}$. The correlations were examined (Table 2) for three different periods during the field season that coincided with the largest number of simultaneous

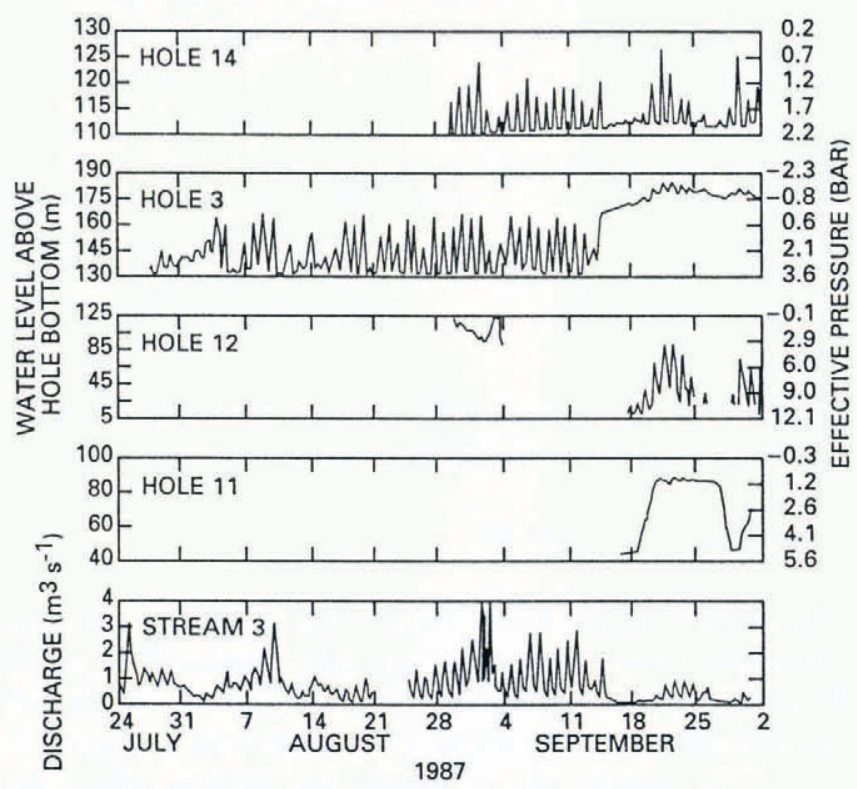

Fig. 6. Water-level variations in the boreholes in the transverse profile, including stream-flow. 
Table 2. Correlation matrix between boreholes in 1987 showing the lag with the strongest correlation. $Q$ is the stream discharge. A number above the slash is the correlation coefficient and below the slash is the lag in hours. A positive lag indicates the column variable occurs later in time than (after) the row variable. Bold face indicates a correlation coefficient greater than 0.5

\begin{tabular}{|c|c|c|c|c|c|c|c|c|}
\hline Borehole & $Q$ & 1 & 3 & $5 b$ & 05 & 8 & 12 & 14 \\
\hline \multicolumn{9}{|c|}{31 July-13 August } \\
\hline 1 & $0.39 /-7$ & & & & & & & \\
\hline 3 & $0.86 /-2$ & $0.39 / 4$ & & & & & & \\
\hline $5 b$ & $0.35 / 5$ & $0.28 / 24$ & $0.45 /-19$ & & & & & \\
\hline O5 & $0.21 /-13$ & $0.24 /-17$ & $0.15 /-13$ & $0.15 / 20$ & & & & \\
\hline 8 & $0.66 / 2$ & $0.43 / 8$ & $0.69 / 5$ & $0.21 / 22$ & $0.11 /-1$ & & & \\
\hline \multicolumn{9}{|c|}{26 August-1 September } \\
\hline 1 & $0.72 /-4$ & & & & & & & \\
\hline 3 & $0.83 /-2$ & $0.58 / 2$ & & & & & & \\
\hline $5 b$ & $0.37 / 1$ & $0.37 / 6$ & $0.33 / 1,2$ & & & & & \\
\hline O5 & $0.40 /-11$ & $0.45 /-5$ & $0.35 /-10$ & $0.30 /-13$ & & & & \\
\hline 8 & $0.56 / 1$ & $0.60 / 5$ & $0.73 / 3$ & $0.28 / 0$ & $0.27 / 15$ & & & \\
\hline \multicolumn{9}{|c|}{ 19-29 September } \\
\hline 3 & $0.88 / 1$ & & & & & & & \\
\hline O5 & $0.14 / 4$ & & $0.20 /-24$ & & & & & \\
\hline 8 & $0.51 / 2$ & & $0.64 / 1$ & & $0.13 /-14$ & & & \\
\hline 12 & $0.86 / 0$ & & $0.90 /-1$ & & $0.13 / 24$ & $0.61 / 2$ & & \\
\hline 14 & $0.63 / 2$ & & $0.75 / 1$ & & $0.11 /-14$ & $0.86 / 0$ & $0.73 / 2$ & \\
\hline 15 & $0.67 / 3$ & & $0.77 / 2$ & & $0.12 / 24$ & $0.82 / 1$ & $0.76 / 3$ & $0.93 / 1$ \\
\hline
\end{tabular}

recordings: 31 July-13 August (early August), 26 August1 September (late August) and 19-29 September (late September).

The correlation and phase differences between boreholes are not necessarily constant through the summer. For example, the variations in boreholes 3 and 8 were continuously monitored from early August through late September and their correlation with stream-discharge changes during that period. In hole 3 , during early and late August the changes in water level followed the discharge by $2 \mathrm{~h}$ and, in late September, they preceded the discharge by $1 \mathrm{~h}$. In contrast, the variations in hole 8 preceded the variations in stream discharge by $1-2 \mathrm{~h}$ during the entire season. These different patterns indicate that the hydraulic connection between a borehole and the subglacial hydraulic system can be quite individual.

\section{GENERAL GHARACTERISTICS OF THE SUB- GLACIAL HYDRAULIC REGIME}

\section{High-pressure regime}

About $50 \%$ of the boreholes drilled to the glacier bed connected with a subglacial hydraulic system. This result is similar to that reported by Hodge (1976), who found that $55-60 \%$ of his boreholes connected with a subglacial hydraulic system. In a subsequent drilling effort by Hodge (1979), the percentage of connected holes dropped to $10 \%$. Although Hodge ascribed this change to a temporal change in subglacial hydraulic conditions, his second drilling effort shifted location from the lower and middle ablation zone to the uppermost part of the ablation zone and lower part of the accumulation zone. Results from my work indicate that of the boreholes at or below the equilibrium line (elevation $\sim 1865 \mathrm{~m}$ ) about $73 \%$ connected and, above the equilibrium line, about $38 \%$ connected. Although the borehole locations were not uniformly or randomly spaced, these two data sets suggest that there are spatial differences in subglacial hydraulic connectivity. Within these broad regions there was no spatial pattern to connected and unconnected boreholes, which suggests that the bed is not uniformly connected but rather heterogeneous.

The hydraulic resistance of the connected regions is high relative to that expected for conduit flow. This conclusion is based on two observations: (1) the pressure of the system is generally close to the overburden pressure of the ice (Fig. 3; Table 1); (2) the diurnal water-level variations in the boreholes and stream-flow are either uncorrelated or correlated with significant phase shifts (Table 2). Although Röthlisberger's (1972) calculation for water pressure in a conduit can generally explain the observed pressures, it can only do so with unrealistic values for ice rheology. Furthermore, one would expect pressure waves to propagate quickly through a waterfilled conduit rather than at observed time lags of a few hours. It is also unlikely that the water pressures can be explained by linked cavities (Walder, 1986; Kamb, 1987) because it is unlikely that linked cavities would form 
under the slow-moving ice flowing up an adverse slope (Fig. 3). Also, one would expect synchronous variations in boreholes relatively close together (Iken and Bindschadler, 1986); however, no such behavior is indicated at South Cascade Glacier (Figs 5 and 6). The most promising hypothesis is a porous subglacial debris layer. Such a layer could provide sufficient hydraulic resistance to maintain high water pressures and delay the propagation of pressure waves. However, if such a layer does exist, it is not continuous but occurs in patches or its permeability is highly heterogeneous to explain the frequency of unconnected boreholes.

\section{Low-pressure regime}

Figure 3 indicates a region of relatively low pressure around borehole 12. The water level is not only low but also occasionally falls below the pressure transducer located $5.5 \mathrm{~m}$ above the bottom of the hole, indicating near atmospheric pressure. The variations in water level are quite large (Fig. 6) and are in phase with the stream discharge (Table 2). Taken together, these observations indicate the presence of a subglacial conduit in the vicinity of borehole 12 . The presence of a low-pressure feature, such as a conduit, in a region of otherwise high hydraulic head, suggests that two coupled systems exist: a relatively low-pressure conduit draining water from the surrounding high-pressure debris layer. Qualitative evidence for this coupling is presented in Figure 7, the transverse profile of borehole water levels. The trend of water levels in neighboring boreholes indicates a subglacial hydraulic gradient driving water towards borehole 12.

The transverse profile is located on the down-glacier side of an enclosed subglacial basin (overdeepening) (Fig. 3 ) and borehole 12 is located on the lefthand side of the

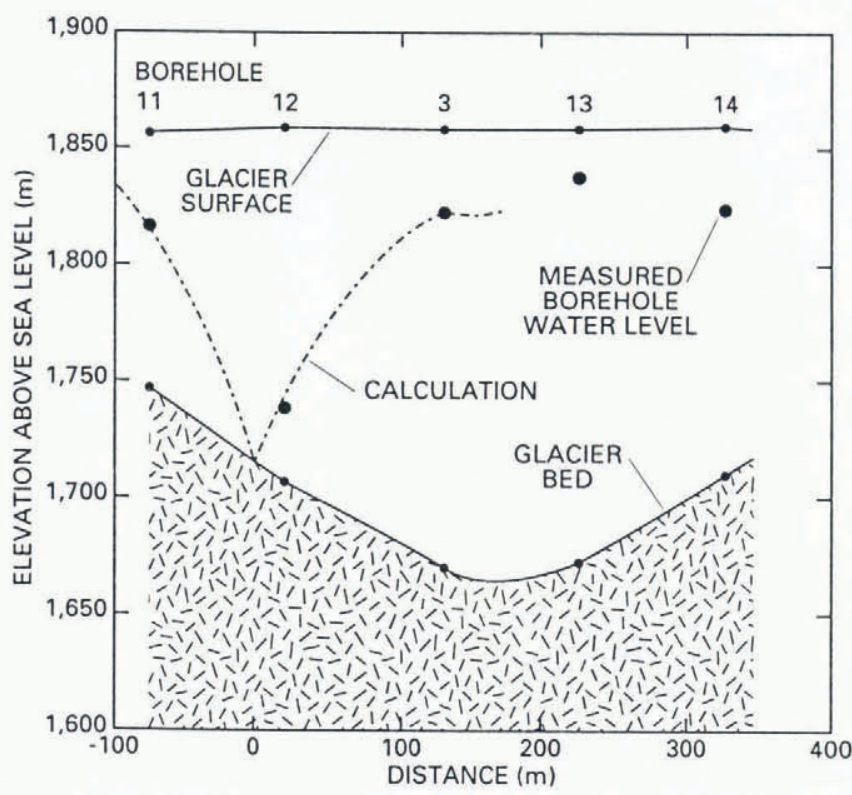

Fig. 7. Transverse profile of mean water levels measured in boreholes. The solid circles are the measured data: icesurface elevations measured by theodolite, mean water levels measured by pressure transducer and glacier-bed elevations measured from the surface by drilling. The dashed line is the calculated water level from Equation (3). basin. The path of the conduit, down-glacier from the transverse profile, is inferred from the drainage pattern of injected tracers (Fig. 1). The conduit probably exists under the narrow drainage strip. The path of the conduit up-glacier from the transverse profile probably follows along the western (lefthand) margin of the glacier for some unknown distance. It seems that conduits avoid the deepest part of overdeepenings based on the inferred conduit location at South Cascade Glacier. Similarly, observations of Hantz and Lliboutry (1983) at Glacier d'Argentière indicate high borehole water levels across an enclosed subglacial basin with lower water levels in one or two boreholes near the glacier margin.

\section{HYDRAULIC PROPERTIES OF THE SUB- GLACIAL LAYER}

Although borehole-response tests (Stone and Clarke, 1993) provide a relatively controlled measure of the hydraulic properties of the subglacial layer, they can also be inferred from the average water levels and the natural variations. For the latter situation, used in this study, the key assumption is the existence of a subglacial conduit, which provides a hydraulic sink for water moving through the layer. The second assumption is that flow in the layer is Darcian and the layer is homogeneous. This last assumption is contrary to the patchy connectivity implied by some boreholes connecting to a subglacial hydraulic system while others do not connect. However, given that the areal extent of the connected regions is unknown, the layer will be assumed to be uniform. Both analyses will be applied to the water levels in the transverse profile (Fig. 7) which is considered to be perpendicular to the conduit path.

\section{Analysis of average water levels}

To estimate the distribution of subglacial water pressure, it was assumed that subglacial water is flowing in a permeable debris layer at the base of the glacier between the ice and bedrock (Fig. 8) in a Darcian manner such that

$$
Q=T \frac{\mathrm{d} \Phi}{\mathrm{d} y}
$$

where $Q$ is the subglacial water discharge per unit width, $T$ is the transmissivity (product of the permeability and layer thickness) of the debris layer, $\Phi$ is the total head and equal to the sum of mean water head and bed elevation, and $y$ is distance measured normal to the channel. The water flux in the layer is equal to

$$
Q=I(Y-y)
$$

where $I$ is the influx of water to the debris layer per unit area and $Y$ is the distance to an impermeable hydrologic boundary such as a water divide or the edge of the glacier. Equating Equations (1) and (2), and integrating (assuming $T$ to be constant), yields

$$
\Phi=\frac{I}{T}\left(Y y-\frac{1}{2} y^{2}\right)+\Phi_{\mathrm{o}}
$$


GLACIER SURFACE

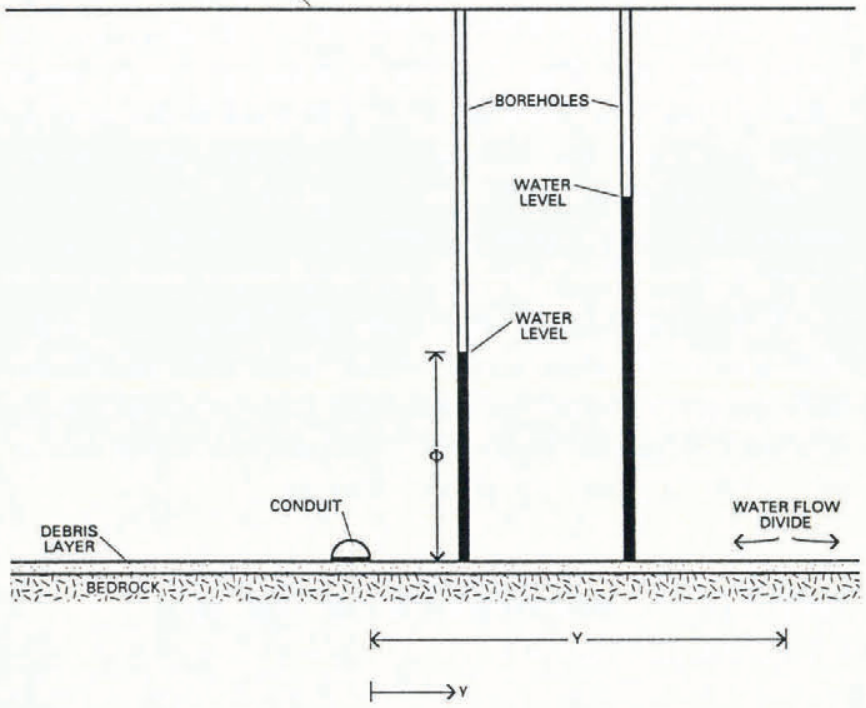

Fig. 8. Transverse cross-section of the glacier near the transverse profile of boreholes showing a hypothetical debris layer. The symbols define the terms in Equation (3).

where $\Phi$ is the mean hydraulic pressure head in terms of water height, and $\Phi_{0}$ is the reference pressure head when $y=0$. This result is identical to that for steady groundwater flow in confined aquifers having vertical accretion (McWhorter and Sunada, 1981) and was used by Shoemaker (1986) for his analysis of subglacial water flow in debris. The problem is poorly constrained, however, because there are three unknowns: the ratio of the infiltration rate to transmissivity and distance from the conduit to each hydrologic boundary, and two equations, one for each side of the channel. It was assumed that the infiltration rate and transmissivity were the same for both sides of the channel. There are an infinite number of solutions because for each $Y$, which can range from zero to the edge of the glacier, there will be a given $I / T$. To limit the solution set, the largest value for $Y$ that still yields a good fit to the data was calculated. This minimizes the magnitude of $I / T$. The calculated water height was matched to the measured water height by adjusting the distance to the hydrologic boundaries and the magnitude of the ratio of infiltration rate to transmissivity in Equation (3).

The results of the calculations are presented in Figure 7. The borehole was estimated to be about $20 \mathrm{~m}$ from the conduit and the hydrologic boundaries were estimated to be $125 \mathrm{~m}$ to the left of the conduit and $180 \mathrm{~m}$ to the right. The right hydrologic boundary is estimated to be between boreholes 3 and 13, over the deepest part of the glacier in this cross-section. A tracer injection into borehole 14 showed that, although the subglacial flow drained to stream 3 (Fountain, 1993), an adjacent surface injection drained to stream 2, which violates the assumption of constant surface drainage along the profile. The ratio of surface infiltration to transmissivity of the subglacial layer was $0.01 \mathrm{~m}^{-1}$.

The range of transmissivities of the subglacial layer can be estimated from the range of meltwater flux to the layer. A lower limit can be estimated by assuming that the meltwater flux is generated by frictional heating as the ice slides over the bed. For values typical of the region around the transverse profile the specific melt rate is roughly $10^{-10} \mathrm{~m} \mathrm{~s}^{-1}$. The corresponding transmissivity is $10^{-8} \mathrm{~m}^{2} \mathrm{~s}^{-1}$. An upper limit can be estimated by assuming that all the surface melt reaches the glacier bed. The average surface melt, based on ablation-stake measurements, for the period of time that the water levels were monitored was approximately $4.4 \times 10^{-7} \mathrm{~m} \mathrm{~s}^{-1}$, resulting in an estimated transmissivity of about $4 \times 10^{-5} \mathrm{~m}^{2} \mathrm{~s}^{-1}$. If the subglacial debris layer is approximately $0.1 \mathrm{~m}$ thick, as suggested by Hodge (1976), its range of hydraulic conductivity would be $10^{-7}-10^{-4} \mathrm{~ms}^{-1}$ and is in midrange for a clean sand (Freeze and Cherry, 1979, p. 29).

\section{Diurnal variations}

The dominant period in the fluctuation of most borehole water levels is diurnal. The relative phasing between boreholes and correlation with stream flow provides information about the permeability of the basal layer and movement of subglacial water.

The water-level variations in borehole 12 are in phase with stream discharge and the foregoing analysis of mean water levels in the transverse profile indicated that borehole 12 is about $20 \mathrm{~m}$ away from a subglacial conduit. These findings indicate that the variations in borehole 12 probably result from pressure fluctuations propagating from the conduit. Variations in borehole 3 lag behind the stream variations by $2 \mathrm{~h}$ in July and August and may also result from pressure fluctuations in a subglacial conduit.

The hydraulic properties of the subglacial debris layer can be determined from the increasing time lag of pressure variations or, alternatively, the increased damping of the pressure amplitude with distance away from the conduit. However, there are no direct measurements of pressure in the conduit, which precludes analysis of the pressure amplitude. Fortunately, the timing of stream-flow variation can be used as a proxy indicator of the timing of pressure variation in the conduit.

A hypothetical arrangement is a semi-infinite plane, representing the subglacial layer (Fig. 9). The sinusoidal pressure variations in an infinitely long subglacial conduit form a boundary condition at one edge. Both the conduit and subglacial debris layer are confined by ice above and

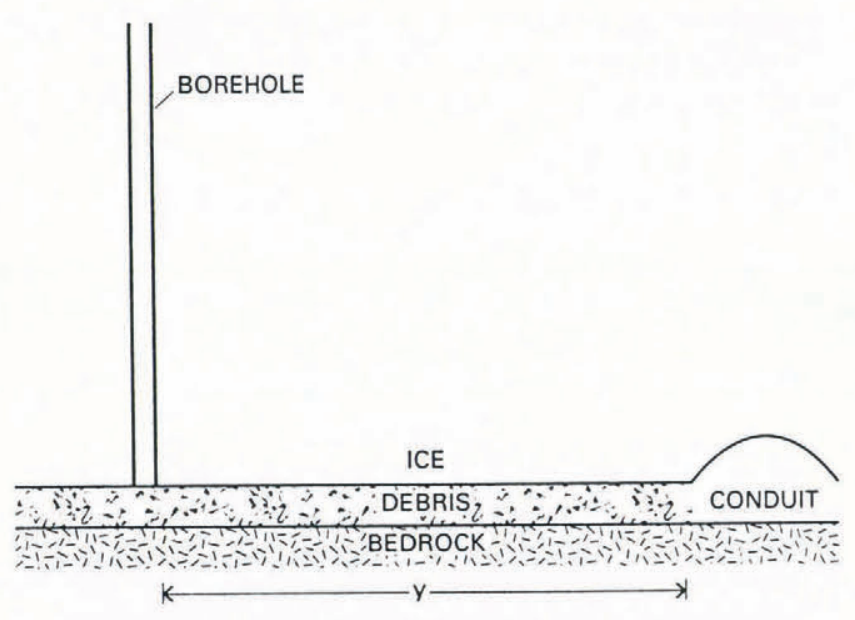

Fig. 9. Definition sketch for Equation (4) depicting a subglacial conduit connected to a debris layer. 
bedrock below. Because the pressure variations are probably large compared to the thickness of the subglacial layer, vertical differences in pressure within the layer can be ignored. The borehole water-level measurements represent point measurements of pressure in the subglacial layer. The propagation of pressure in one dimension with a boundary condition at one end and a steady-state pressure at infinity can be described by a linear second-order equation. The solution to this problem is common to heat flow in the Earth where the surface temperature varies on a sinusoidal cycle (Ingersoll and others, 1954). The time at which the pressure maxima (or minima) will occur at any point can be shown as

$$
t=y \sqrt{\frac{S_{8}}{2 w K}}
$$

where $t$ is the lag time of pressure maxima in the subglacial layer at distance $y$ from the source at the conduit, $w$ is the angular frequency of the periodic boundary condition and for a diurnal variation is equal to $7.27 \times 10^{-5} \mathrm{~s}^{-1}(2 \pi / 24 \mathrm{~h}), S_{\mathrm{s}}$ is the specific storage of the layer, ranging from $10^{-4}$ to $10^{-7} \mathrm{~m}^{-1}$ for a sand or gravel, and $K$ is the hydraulic conductivity of the layer. Rearranging Equation (4) to solve for hydraulic conductivity yields

$$
K=\frac{S_{8}}{2 w\left(\frac{t}{y}\right)^{2}}
$$

The variations in borehole 3 for the period of earlylate August were interpreted in terms of Equation (5). The analysis of steady-state water levels in the transverse profile indicates its distance from a subglacial conduit is $129 \mathrm{~m}$ and the lag time between variations in stream discharge (a proxy indicator of pressure variations in the conduit) and borehole water-level variations was $2 \mathrm{~h}$. Substituting these values for $y$ and $t$, respectively, the angular frequency and a range of specific storage from $10^{-4}$ to $10^{-7} \mathrm{~m}^{-1}$ yield a range of hydraulic conductivity for the subglacial layer of $10^{-4}-10^{-7} \mathrm{~m} \mathrm{~s}^{-1}$.

The same analysis was applied to borehole $12(20 \mathrm{~m}$ from the subglacial conduit) with a time lag after stream discharge of no more than about $20 \mathrm{~m}$. The crosscorrelation analysis (Table 2) indicated zero lag between stream discharge and water-level variations but could not discriminate times less than the hourly interval between measurements. The resulting hydraulic conductivity range is also $10^{-4}-10^{-7} \mathrm{~m} \mathrm{~s}^{-1}$.

The range of hydraulic conductivity inferred from both boreholes, $10^{-4}-10^{-7} \mathrm{~m} \mathrm{~s}^{-1}$, is consistent with the conductivity range estimated by the steady-state analysis. That these two approaches yield the same range of values is encouraging. The range of values, however, is higher than a laboratory measurement of a debris sample from the base of Ice Stream B, Antarctica, which was $2 \times 10^{-9} \mathrm{~m} \mathrm{~s}^{-1}$ (Engelhardt and others, 1990). Also, the inferred conductivity range is higher than that measured in glacial till, which ranges from $10^{-12}$ to $10^{-6} \mathrm{~m} \mathrm{~s}^{-1}$ (Freeze and Cherry, 1979, table 2.2). One significant difference between these conductivities and that inferred from South Cascade Glacier is the latter was derived from in situ measurements. If subglacial water flows along the ice-debris interface, in addition to within the debris, then the conductivity inferred from in-situ measurements would be larger than those based on laboratory or ground-water measurements where the water flows only within the porous matrix.

\section{SEASONAL EVOLUTION OF THE SUBGLACIAL HYDRAULIC REGIME}

The water-level variations for periods greater than $24 \mathrm{~h}$ were found by filtering the data to remove the diurnal variations (Walters and Heston, 1982). The general trend of these variations is towards higher pressures as the season progresses (Fig. 10). The boreholes in the transverse profile are not shown because of their relatively short record. During the two months of August and September, the water pressure increased by about $60 \%$ in borehole $1,20 \%$ in boreholes 3 , O5 and 8 , and $3 \%$ in borehole $5 \mathrm{~b}$. This trend of increasing pressure is not generally correlated with surface water input and stream discharge (a measure of water flux through the glacier) and suggests other subglacial processes. The exception is the trend in borehole 3 , which is inversely correlated with surface input as inspection of Figure 10 will reveal.

It is difficult to explain the gradually increasing water level in all the boreholes by any one process because of the number of different processes than can occur combined with a lack of information about changes in the borehole itself and surrounding subglacial environment. The various processes that can occur include closure of the
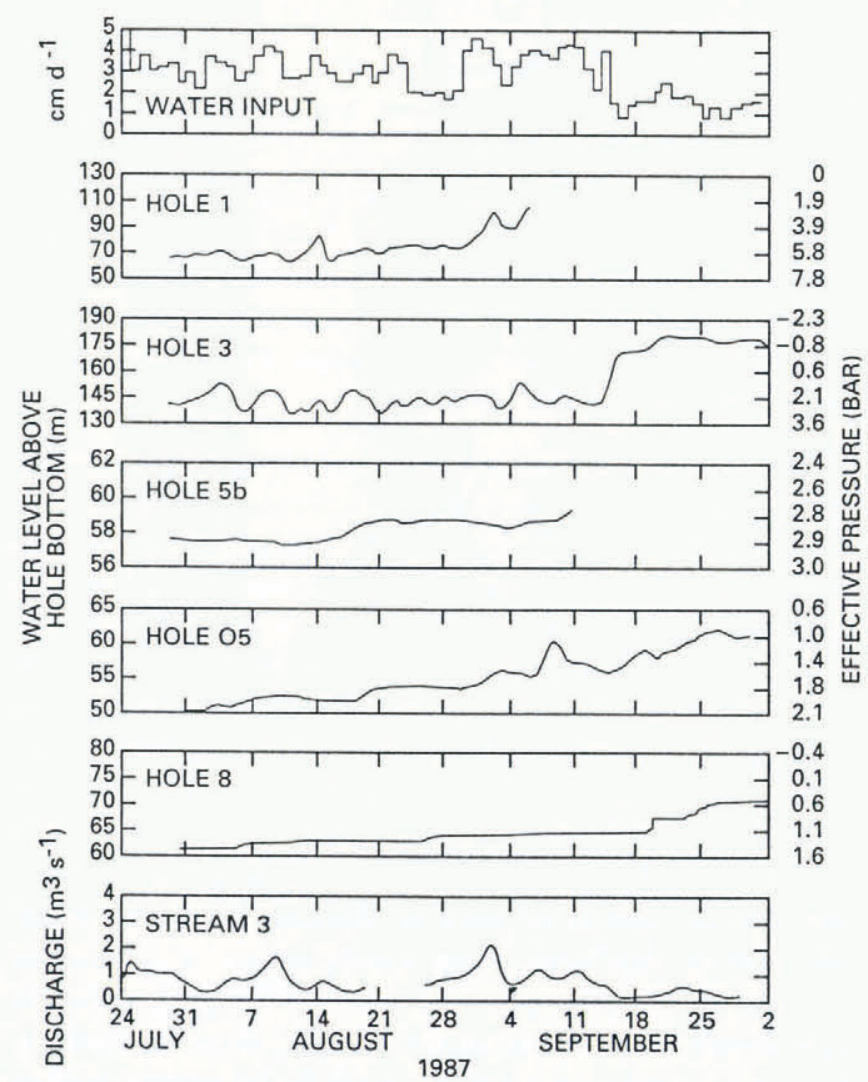

Fig. 10. Smoothed water levels (variations at periods of $24 \mathrm{~h}$ or less were removed) for the longitudinal profile. 
borehole and the passage between the borehole and subglacial system, advection of a borehole across the bed, an increase in conduit pressure and a decrease in the transmissivity of the subglacial layer.

(1) Closure. The deformation of ice, caused by hydrostatic pressure, will close any opening in the ice. To increase the water level, the borehole or passage would have to decrease significantly in size to increase the hydraulic resistance. The radius of the borehole, about $10 \mathrm{~cm}$, will

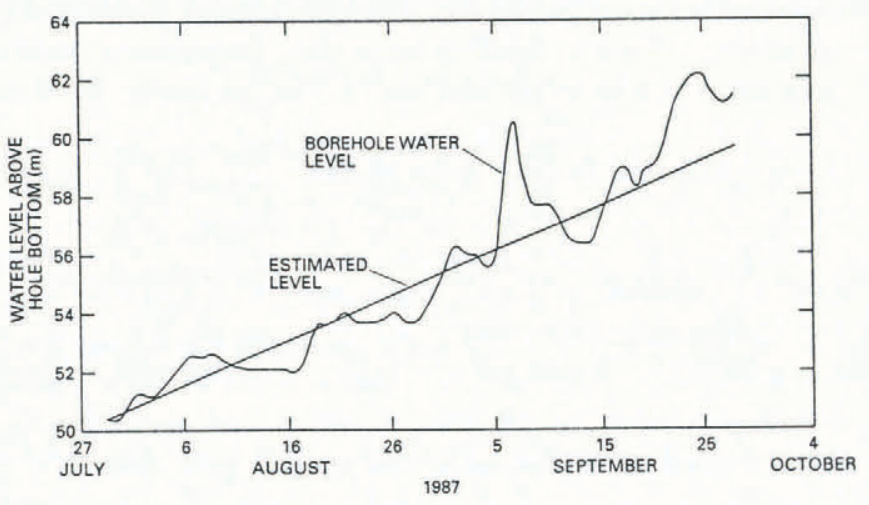

Fig. 11. The calculated long-term increase in water pressure (dashed line) compared to the measured increase in borehole water height.

shrink by only $17 \%$ after 3 months with an effective pressure of $6 \mathrm{bar}$, the largest effective pressure observed in Figure 10. Furthermore, this closure rate does not include the compensating effects of enlargement by water flowing into the borehole. Thus, closure by itself cannot explain the increasing water levels.

(2) Borehole advection. As the glacier moves downhill, the borehole is advected along and encounters other regions of the bed. It may be possible for a borehole or the passage between the borehole and subglacial system to encounter subglacial obstacles (Hantz and Lliboutry, 1983) that would obstruct the passage and increase the hydraulic resistance. This may explain the sudden jumps in water level and why such jumps are not detected simultaneously in other boreholes.

(3) Increase in conduit pressure. Subglacial water drains from the distributed high-pressure system to the relatively lowpressure channelized conduit. If the conduit pressure increases, the pressure in the distributed system would increase. Röthlisberger (1972) showed that, for steadystate conditions, conduit discharge and pressure are inversely related. However, there is no correlation between long-term changes of stream discharge and increasing trend of water pressure (Fig. 10). The one possible exception is borehole 3 starting in midSeptember. In that case, the borehole water-level increase is coincident with a decrease in water input and stream discharge. One would expect a coincident increase in the pressure of borehole 12 (Fig. 7) which is considered much closer to the conduit than borehole 3 . However, borehole 12 indicated subglacial pressures close to atmospheric during the period when borehole 3 exhibited pressures close to overburden. Increased pressure in that conduit cannot explain the increase in borehole water levels.

(4) A decrease in transmissivity of the subglacial layer would increase the subglacial pressure. If we choose $20 \%$ as the representative increase for basal water pressures, which represents a $20 \%$ increase in pressure gradient assuming constant pressure at the conduit, the transmissivity has to decrease by $20 \%$. This may be accomplished by thinning a subglacial debris layer or decreasing its permeability.

To estimate a decrease in the thickness of the subglacial debris layer, subglacial erosion was estimated using the suspended sediment measured in stream 3 (Fountain, 1992). Assuming that most of the erosion is taking place in the lower corridor of the stream 3 basin, the estimated thinning is about one-third of that required to reduce the debris thickness by $20 \%$. Considering the conservative estimates of debris thickness and area, and that the compensating effect of bedrock erosion was ignored, the actual thinning may be much less.

A decreasing hydraulic conductivity can result from small particles that infiltrate into the debris matrix and increase its resistance to water flow. Glacial abrasion and grinding of the till provide a source of fine particles. The Kozeny-Carmen equation (see Appendix) was used to estimate qualitatively the changing hydraulic conductivity and shows the hydraulic conductivity can be reduced by $20 \%$. This process could explain the evolution of subglacial water pressures.

Based on the idea that particle infiltration into a debris layer causes reduced permeability, an hypothesis for the seasonal evolution of subglacial pressures is proposed. At the start of the ablation season, high water pressures are created at the bed by meltwater accumulating in englacial passages that connect the ice surface to the bed. The subglacial pressures are near or locally exceed overburden pressure and, as the glacier is locally lifted, water accumulates in subglacial pockets. This process qualitatively explains the observed uplift of glaciers in spring (Iken and others, 1983). These highpressure regions connect with low-pressure regions, such as remnant subglacial conduits or the lee side of irregularities in the basal topography. Once connected, the water flows out of the englacial connections and flushes the subglacial debris of fine particulates or, in some cases, may erode the coarser matrix. This probably occurs in discrete flow paths rather than as sheet flow (Walder, 1982). This process explains the seasonal fluctuation of suspended sediment in streams with much more sediment in the spring months than the later summer months (Østrem and others, 1967). The permeable flow paths continue to drain subglacial water to conduits through much of the summer. As the ablation season progresses, the discrete flow paths decrease in permeability as particles, created by subglacial erosion, infiltrate the porous layer. This explains the gradual increase in pressure during the season. The pressure is limited, however, by the flux of meltwater to the bed, which starts to decrease in late summer. Finally, little or no surface meltwater is generated and the only water source is from bottom melting created from the frictional drag of the ice sliding over the bed. Although water 
continues to drain from the glacier during winter, subglacial conduits and feeder passages close, reducing the water flux from the glacier and thus maintaining high subglacial water pressure.

\section{SUMMARY AND GONGLUSIONS}

Sudden decreases in water levels, measured in boreholes not completed to the bed, were often observed, indicating connections with crevasses or englacial passages. Occasionally, a rapid drop in water level was observed when a borehole just reached the bed. In one case in which the water levels were monitored, the decreasing water level was successfully modeled by the rapid enlargement of a small passage between the borehole and a subglacial region at constant pressure.

Several lines of evidence indicate that much of the subglacial region is underlain by a debris-like layer that drains to a conduit. The debris layer is characterized by relatively high water pressure, and damping and delay of pressure waves propagating through the medium. The layer is not homogeneous but has permeable and impermeable regions, as indicated by connected and unconnected boreholes. These results are consistent with previous findings at South Cascade Glacier and at other glaciers. Furthermore, a larger fraction of boreholes connected in the ablation zone are comparable to those in the accumulation zone, indicating a higher subglacial connectivity in the ablation zone. This spatial change in connectivity is an important consideration for studies assessing temporal hydraulic changes. The existence of a subglacial conduit is inferred from large variations in the water levels of borehole 12, which oscillated in phase with the stream-flow variations and occasionally reached near atmospheric conditions. Darcian flow in a subglacial layer, draining to a conduit can explain the observed mean water levels in the transverse profile of boreholes. From this analysis, borehole 12 was inferred to be about $20 \mathrm{~m}$ from the conduit. The lag time in the diurnal cycle between water-level variations in two boreholes and stream discharge, a proxy for pressure variations in a subglacial conduit, were used to determine the hydraulic conductivity of the subglacial layer. Both analyses suggested that the hydraulic conductivity of the subglacial layer ranges from $10^{-7}$ to $10^{-4} \mathrm{~m} \mathrm{~s}^{-1}$.

During the latter half of the summer season, borehole water levels generally increased. This trend indicates a progressive change in the subglacial hydraulic systems and may reflect a natural evolution in subglacial hydraulics. This evolution may be caused by a decreasing permeability of the subglacial debris resulting from the infiltration of fine particles created during subglacial erosion. However, some variation in water level may also result from evolution of the hydraulic connection between the borehole and subglacial hydraulic system. This is indicated by boreholes that connected to the hydraulic system some time after drilling was completed and those that later disconnected from the hydraulic system.

Together, these results indicate that the subglacial hydraulic system evolves during the season and exhibits a large degree of spatial heterogeneity. This surprising complexity needs to be further investigated to understand better the processes of subglacial water movement.

\section{ACKNOWLEDGEMENTS}

I am greatly indebted to B. Vaughn, formerly of the U.S. Geological Survey and presently at the University of Colorado, who provided much needed encouragement and skill during the construction of the drill, which made this project possible. A. Reece of Hiline Helicopters flew the heavy drilling equipment into South Cascade Glacier, often during marginal conditions, and often made special arrangements to suit my schedule. Field assistance is always appreciated and several people kindly volunteered their time to help drill on the glacier and they include B. Vaughn, P. Danes, C. Quintana, E. Banta, G. Boyce, M. Fahnestock and C. Raymond. This manuscript was significantly improved by the careful editing of S. Burges, V. Butler, C. Raymond and J. Walder.

\section{REFERENGES}

Bear, J. 1972. Dynamics of fluids in porous media. New York, American Elsevier.

Boulton, G.S. and R. C.A. Hindmarsh. 1987. Sediment deformation beneath glaciers: rheology and geological consequences. F. Geophys. Res., 92(B9), 9059-9082.

Engelhardt, H. 1978. Water in glaciers: observations and theory of the behaviour of water levels in boreholes. Z. Gletscherkd. Glaziolgeol., 14(1), 35-60.

Engelhardt, H., N. Humphrey, B. Kamb and M. Fahnestock. 1990. Physical conditions at the base of a fast moving Antarctic ice stream. Science, 248(4951), 57-59.

Fountain, A.G. 1992. Subglacial water flow inferred from stream measurements at South Cascade Glacier, Washington State, U.S.A. J. Glaciol., 38(128), 51-64.

Fountain, A. G. 1993. Geometry and flow conditions of subglacial water at South Cascade Glacier, Washington State, U.S.A.; an analysis of tracer injections. 7. Glaciol., 39(131), 143-156.

Freeze, R. A. and J. A. Cherry. 1979. Groundwater. Englewood Cliffs, NJ, Prentice-Hall.

Hantz, D. and L. Lliboutry. 1983. Waterways, ice permeability at depth, and water pressures at Glacier d'Argentière, French Alps. f. Glaciol., 29(102), 227-239.

Hodge, S. M. 1976. Direct measurement of basal water pressures: a pilot study. J. Glaciol., 16(74), 205-218.

Hodge, S.M. 1979. Direct measurement of basal water pressures: progress and problems. J. Glaciol., 23(89), 309-319.

Hooke, R. Le B., S.B. Miller and J. Kohler. 1988. Character of the englacial and subglacial drainage system in the upper part of the ablation area of Storglaciären, Sweden. J. Glaciol., 34(117), 228-231.

Iken, A. and R.A. Bindschadler. 1986. Combined measurements of subglacial water pressure and surface velocity of Findelengletscher, Switzerland: conclusions about drainage system and sliding mechanism. J. Glaciol., 32(110), 101-119.

Iken, A., H. Röthlisberger, A. Flotron and W. Haeberli. 1983. The uplift of Unteraargletscher at the beginning of the melt season - a consequence of water storage at the bed? 7 . Glaciol., 29(101), 28-47.

Ingersoll, L.R., O.J. Zobel and A. C. Ingersoll. 1954. Heat conduction. Madison, WI, University of Wisconsin Press.

Kamb, B. 1987. Glacier surge mechanism based on linked cavity configuration of the basal water conduit system. F. Geophys. Res., 92(B9), 9083-9100.

Kamb, B. and H. Engelhardt. 1987. Waves of accelerated motion in a glacier approaching surge: the mini-surges of Variegated Glacier, Alaska, U.S.A. J. Glaciol., 33(113), 27-46.

McWhorter, D. and D. K. Sunada. 1981. Ground-water hydrology and hydraulics. Littleton, Water Resources Publications.

Østrem, G., C. W. Bridge and W.F. Rannie. 1967. Glacio-hydrology, discharge and sediment transport in the Decade Glacier area, Baffin Island, N.W.T. Geogr. Ann., 49A(2-4), 268-282.

Röthlisberger, H. 1972. Water pressure in intra- and subglacial channels. f. Glaciol., 11(62), 177-203. 
Shoemaker, E. M. 1986. Subglacial hydrology for an ice sheet resting on a deformable aquifer. F. Glaciol., 32(110), 20-30.

Stone, D.B. and G.K.C. Clarke. 1993. Estimation of subglacial hydraulic properties from induced changes in basal water pressure: a theoretical framework for borehole-response tests. J. Glaciol., 39(132), 327-340.

Taylor, P. L. 1984. A hot water drill for temperate ice. CRREL Spec. Rep. 84-34, 105-117.

Walder, J.S. 1982. Stability of sheet flow of water beneath temperate glaciers and implications for glacier surging. J. Glaciol., 28(99), 273-293.

Walder, J. S. 1986. Hydraulics of subglacial cavities. F. Glaciol., 32(112), $439-445$.

Walters, R.A. and C. Heston. 1982. Removing tidal-period variations from time-series data using low-pass digital filters. F. Phys. Oceanogr., 12(1), 113-115.

The accuracy of references in the text and in this list is the responsibility of the authors, to whom queries should be addressed.

\section{APPENDIX}

\section{DECREASING DEBRIS PERMEABILITY}

\section{Time-dependent hydraulic conductivity}

The infiltration of small particles into subglacial debris can change the hydraulic conductivity of the debris. Subglacial erosion provides a source of small particles. The relation between hydraulic conductivity and grainsize is given by the Kozeny-Carmen equation (Bear, 1972)

$$
K=\frac{\rho g}{\mu}\left[\frac{\phi^{3}}{(1-\phi)^{2}}\right] \frac{d_{\mathrm{m}}^{2}}{180}
$$

where $\rho$ is water density, $g$ is gravity, $\mu$ is viscosity, $\phi$ is porosity and $d_{\mathrm{m}}$ is a characteristic grain-size of the debris. Although the Kozeny-Carmen equation assumes steadystate conditions and a well-sorted matrix, rather than the poorly sorted debris characteristic of glacial till, its use here is to examine the potential validity of a process rather than make accurate predictions. Porosity has been assumed constant so the change in hydraulic conductivity is caused by a change in the characteristic grain-size. If porosity was allowed to change, the infiltration of smaller particles would decrease the porosity and decrease the conductivity faster than that calculated from the characteristic grain-size alone.

It is assumed that the characteristic grain-size is represented by $d_{50}$, the mean size of the grains

$$
d_{50}=\frac{\sum_{i=1}^{N} d_{i}}{N}
$$

where $N$ is the total number of grains per unit area and $d$ is the grain diameter. The total number of grains, $N$, is a function of time because newly created particles are added. $N$ can be expanded into a steady-state term and time-dependent term

$$
N=N_{\mathrm{o}}+R t
$$

where $N_{\mathrm{o}}$ is the initial number of grains, $R$ is the constant production rate of new particles and $t$ is time. Substituting Equation (A3) into Equation (A2)

$$
d_{50}=\frac{\sum_{i=1}^{N_{0}} D+\sum_{i=0}^{R t} d_{x}}{N_{\mathrm{o}}+R t}
$$

where $D$ is the initial mean grain diameter and $d_{x}$ is the diameter of the infiltrating particles. The first summation term is a constant and is equal to $N_{\mathrm{o}} D$. If it is assumed that the newly eroded particles all have the same diameter, then $d_{x}$ is also a constant and the second summation term is equal to $d_{x} R t$. Making these substitutions into Equation (A4) yields

$$
d_{50}=\frac{N_{0} D+d_{x} R t}{N_{\mathrm{o}}+R t} .
$$

Substituting Equation (A5) into Equation (A1) for $d_{m}$ results in dependent hydraulic conductivity

$$
K=G\left[\frac{N_{\mathrm{o}} D+d_{x} R t}{N_{\mathrm{o}}+R t}\right]^{2}
$$

where

$$
G \equiv \frac{\rho g}{180 \mu}\left[\frac{\phi^{3}}{(1-\phi)^{2}}\right] \text {. }
$$

The mean pressure, in terms of water head, has been calculated by Equation (10), based on uniform water input to a confined layer with constant transmissivity

$$
h=\frac{I}{T}\left(Y y-\frac{1}{2} y^{2}\right)+h_{\mathrm{o}}
$$

where $h$ is water pressure in terms of water height, $I$ is the meltwater infiltration rate, $T$ is the transmissivity, $Y$ is the distance from the hydrologic sink (channel) to the impermeable boundary and $y$ is the distance from the sink to the location of interest. The time-dependent hydraulic conductivity, Equation (A6), is substituted into the transmissivity term of Equation (A7) to yield

$$
h=\frac{C}{G}\left[\frac{N_{\mathrm{o}}+R t}{N_{\mathrm{o}} D+d_{x} R t}\right]^{2}
$$

where $C=(I / b)\left(Y y-\frac{1}{2} y^{2}\right)$ and $b$ is the thickness of the subglacial layer. The initial hydraulic conductivity was estimated to be $7.1 \times 10^{-5} \mathrm{~m} \mathrm{~s}^{-1}$, by matching Equation (A7) to the initial water level observed in borehole 8 , using $I=10^{-7} \mathrm{~m} \mathrm{~s}^{-1}, b=0.1 \mathrm{~m}$ and $\left(Y y-\frac{1}{2} y^{2}\right)=3600 \mathrm{~m}^{2}$. All these values are within the range established in the analysis of the steady-state pressures in the transverse profile.

The porosity was 0.3 estimated from Equation (A6) at time zero for the same conductivity estimated by Equation (A7). The initial characteristic grain-size, $D=2.5 \times 10^{-4} \mathrm{~m}$, was determined by inspection of figure 3 in Bolton and Hindmarsh (1987). To match the results of Equation (A8) to the measured values, the rate of particle production, $R$, was adjusted. A close match was achieved for borehole 8 when production rate was $160 \mathrm{~s}^{-1} \mathrm{~m}^{-2}$ (Fig. 11). This rate of particle production is well within the measured suspended mass of particles in the stream water, indicating sufficient erosion and particle-production rates are occurring. The low value of porosity, compared to a more reasonable value of 0.4 0.6 for dilated till (Boulton and Hindmarsh, 1987), may be a result of an overly simplistic calculation of the characteristic grain-size, which is probably an underestimate. These calculations indicate that the infiltration of small particles into subglacial debris can decrease its hydraulic conductivity and explain the observed increase in borehole water level. 